Session 2533

\title{
Outcomes Assessment in an Energy Systems Course
}

\author{
Mark Schumack \\ Department of Mechanical Engineering \\ University of Detroit Mercy
}

\section{Introduction}

Student performance has been traditionally measured through homework assignments, projects, and examinations, with final course grades based on weighted averages of scores in each of these measurement categories. Driven by the EC 2000 criteria, many instructors have revised their course syllabi to list course outcomes and associated linkages to program outcomes. The linkage by itself, however, is insufficient unless suitable evidence is shown that the outcomes have been assessed individually. Course grades provide ambiguous evidence as to how well course outcomes, and consequently program outcomes, have been met. Indeed, ABET documents strongly suggest that course grades are not appropriate assessment indicators for program outcomes $^{1}$. A rigorous course assessment process that isolates student performance for each course outcome will provide clear evidence that course outcomes, and by extension associated program outcomes, are being met.

The development and assessment of course outcomes is instrumental for achieving program educational outcomes. Felder and Brent ${ }^{2}$ provide an excellent resource for designing and teaching courses to satisfy program outcomes. In addition to providing sample course outcomes and instructional methods for addressing EC 2000 criterion 3 outcomes (a) through (k), they provide helpful examples of matrices linking course and program outcomes. Soundarajan ${ }^{3}$ describes an assessment process in computer and information science at Ohio State University that relies on a mechanism called the Course Group Report. The curriculum is divided into groups of related courses. Faculty members responsible for those courses produce a report every two years that addresses, among other issues, how effectively the group of courses is contributing to the relevant program outcomes. Pape and Eddy ${ }^{4}$ describe an assessment methodology in which course assignments and exam problems are linked individually to course outcomes, and subsequently how performance in outcomes is related student grades.

Outcomes assessment in a senior-level energy systems course is described. This course is a senior-level technical elective for mechanical engineering students, and covers topics such as thermodynamic cycles, pump design and piping system analysis, availability analysis, and fuel cells. The assessment process in the College of Engineering \& Science at UDM is summarized, with special attention paid to how courses are used to support program outcomes. The course content and structure are briefly covered, and then the course outcomes assessment process is detailed. Assessment was performed using homework assignments, inclass exercises, written 
essays, and student surveys. Assignments and exam questions were linked with particular course outcomes, and student performance was measured both in terms of outcomes and assessment tool. The analysis resulted in average scores for each outcome, providing a clear picture as to how well the course outcomes were (or were not) satisfied for the class as a whole and for any individual student. The assessment process was tedious the first time it was implemented, but data analysis will become more automated as spreadsheet templates are carried over from one term to another. Finally, refinements to the outcomes assessment process for future offerings are discussed.

\section{The UDM Assessment Process}

The undergraduate engineering programs at the University of Detroit Mercy (Civil \& Environmental, Electrical \& Computer, and Mechanical Engineering) have developed objectives and outcomes in response to constituent needs and requirements of ABET. The assessment process consists of two cycles: a three-year cycle in which program objectives and outcomes are evaluated, and an annual cycle in which program outcomes are assessed. The three-year cycle uses feedback from constituencies to determine the relevance of objectives and outcomes and to make changes if necessary. The annual cycle assesses each of the program outcomes using a variety of tools and reporting mechanisms.

Figures 1 and 2 illustrate the two assessment loops. In the three-year loop, the tools on the left provide information in order to evaluate the validity of the objectives and outcomes. The tools in this case contain information garnered from constituencies such as students, industry, and faculty. Based on this evaluation, changes in objectives and outcomes lead to program improvement as implemented by the responsible parties in the box on the right. Data from the assessment is also used to evaluate whether the objectives are being satisfied.

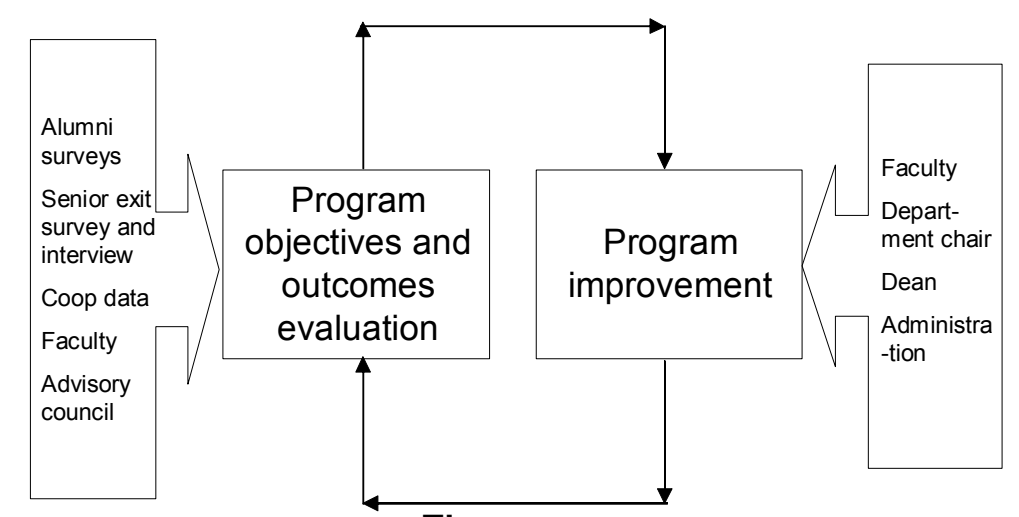

Three years

Figure 1. Program objectives and outcomes evaluation 


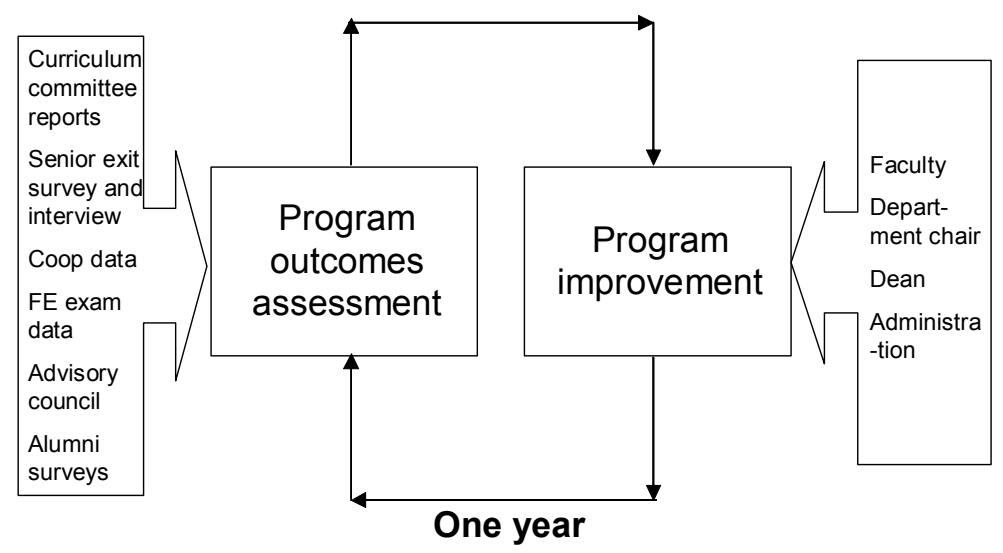

Figure 2. Program outcomes

In the annual loop, program outcomes are assessed. The tools listed in the box at left are used to assess the degree to which the outcomes are satisfied, program improvements are decided upon, and the responsible parties in the right box implement the changes. The tools in the box on the left are representative; individual programs use different tools.

The foundation of the program outcome assessment process is the post-course instructor assessment document, also known as the course worksheet (the form can be seen in the appendix). At the end of a course, the instructor provides a written assessment of how well each of the course outcomes was satisfied. This information, along with linkages between course and program outcomes, helps the department faculty assess how well program outcomes are being met. Near the beginning of every academic term, department curriculum committees meet to discuss course worksheets from the previous term. The number of curriculum committees depends on the program; the mechanical engineering program, for instance, has three curriculum committees covering the areas of design, manufacturing, and thermal sciences. The committees write reports summarizing conclusions and identifying action items for subsequent offerings. The department holds an annual outcome assessment meeting where tools such as coop employer surveys, student exit surveys, FE exam results, curriculum committee reports, advisory council minutes, and alumni surveys are reviewed. The culmination of the yearly process is an annual outcome assessment report, in which each outcome is assessed using results from the applicable tools, and action items for the following year are identified. The report also describes progress on the previous year's action items, thus completing the feedback loop.

As mentioned above, course outcomes support program outcomes. It is therefore important to perform a rigorous assessment of individual outcomes in any given course. The remainder of this paper focuses on the process for outcomes assessment in an energy systems course in the mechanical engineering department offered in Term III of the 2002-03 academic year. 


\section{Energy Systems Course Content and Outcomes Assessment}

Energy Systems is a senior-level technical elective for mechanical engineering students.

Prerequisites include introductory thermodynamics and fluid mechanics. The offering in 200203 had 10 students. Although the topics can vary from year to year depending on student interest, instructor interest, and contemporary energy issues, the current list of topics is given in Table 1.

- Review of thermodynamics

- Energy resource depletion models

- Gas power cycles and jet engines

- Vapor compression and absorption refrigeration cycles

- Availability analysis

- Pumps, compressors, and turbines

- Pump and system head curves

- Wind and/or solar power (as time permits)

- Fuel cells

- Energy storage: flywheels, compressed gas, thermal

\section{Table 1. Energy Systems course topics.}

Course outcomes can also vary somewhat; the current list is given in Table 2.

After taking this course, students will be able to:

1. Understand global energy use and nonrenewable energy source depletion rate models (program outcomes h, j)

2. Design a simple jet engine (program outcome c)

3. Analyze regeneration and reheat enhancements to gas power cycles (program outcomes a, k)

4. Analyze vapor-compression and absorption refrigeration cycles (program outcome a)

5. Perform availability (exergy) analyses on various systems (program outcomes a, k)

6. Analyze operating characteristics of pumps, turbines, and compressors (program outcomes a, k)

7. Use pump and system head curves to size pumps for piping systems (program outcome c)

8. Analyze a variety of alternative-energy systems (program outcomes a, h, j)

9. Apply fundamental fuel cell relationships (program outcome a)

10. Design energy storage systems (program outcome c)

\section{Table 2. Energy Systems course outcomes.}

Linkages with program outcomes are noted parenthetically (the mechanical engineering program outcomes at UDM closely follow the ABET-mandated criterion 3 outcomes (a) through (k)). 
Prior to the outcomes-based approach, a typical grade sheet would contain student scores for homework and inclass assignments, exams, and projects (if applicable), with a final grade based on weighted averages in these categories. In the most recent offering, seven homework assignments and four inclass projects were worth $40 \%$ of the final grade, and three 75 -minute exams were worth $60 \%$. Under the new approach, the previous technique is still followed in order to report a final course grade, but in addition each outcome is assessed using both instructor-given assignments and student self-evaluations.

Outcomes were identified with various assignments as shown in Table 3.

\begin{tabular}{|c|c|c|}
\hline & Assignment & Outcome(s) \\
\hline \multirow{7}{*}{ 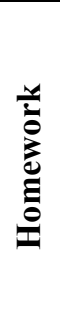 } & 1 & None \\
\hline & 2 & $1,2,3$ \\
\hline & 3 & 3,8 \\
\hline & 4 & $4,6,7$ \\
\hline & 5 & 5 \\
\hline & 6 & 9 \\
\hline & 7 (essay) & 1,8 \\
\hline \multirow{4}{*}{ 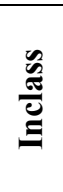 } & 1 & 8 \\
\hline & 2 & 8 \\
\hline & 3 & 10 \\
\hline & 4 & 10 \\
\hline \multirow{4}{*}{ 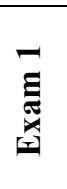 } & Problem 1 & 1 \\
\hline & Problem 2 & none \\
\hline & Problem 3 & 4 \\
\hline & Problem 4 & 4 \\
\hline \multirow{3}{*}{ 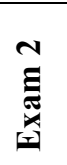 } & Problem 1 & 6 \\
\hline & Problem 2 & 7 \\
\hline & Problem 3 & 8 \\
\hline \multirow{3}{*}{ 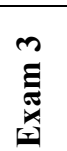 } & Problem 1 & 9 \\
\hline & Problem 2 & 5 \\
\hline & Problem 3 & 10 \\
\hline
\end{tabular}

Table 3. Linkages among class assignments and outcomes

Ideally, the course outcomes, developed while the course is being planned, should drive the assignments. In practice, some of the assignments or exam problems were first given to the students, with the outcome assignment being done after students handed in their work. Thus, some of the outcomes were assessed heavily while others were addressed just once. It may be that the resulting coverage is appropriate, but the coverage for each outcome should be determined prior to designing assignments, not after the fact. Another consequence of this lessthan-rigorous attention to outcomes led to one exam problem being not relevant to any of the course outcomes, which indicates either that the problem should not have been included, or that an outcome needs to be added (the problem concerned evaluation of alternative heating systems and suggests the addition of another outcome regarding comparative energy analyses). 
A few examples will demonstrate how the assignments were linked to outcomes. Homework assignment 6 addressed outcome 9, "apply fundamental fuel cell relationships." The homework assignment included a problem where students had to apply relevant relationships to design a 1 $\mathrm{kW}$ hydrogen fuel cell for given operating conditions. Two of the inclass assignments consisted of quizzes on papers the students were required to read addressing outcome 8, "analyze a variety of alternative energy systems." One article from Mechanical Engineering dealt with power systems to extract energy from ocean currents, and another from the New York Times reported on controversies over windmill site selection. The quizzes were intended mainly to test the students' ability to critically gauge the effectiveness of energy sources and analyze social issues surrounding alternative energy systems, while homework and exam problems linked to this outcome tested their ability to perform technical analyses.

Outcome assessment proceeded as follows. Outcome scores were determined in two categories for each student: homework/inclass assignments and exams. Homework assignments were graded on a $0-100$ scale; exam problems were worth varying points but scores were rescaled to $0-100$. As seen in Table 3, some homework assignments covered more than one outcome. In these cases, each outcome was assigned the overall assignment score; i.e., no attempt was made to assess individual outcomes in any given homework assignment (this is a case where rigor was sacrificed to grading effort and may be changed for future courses, particularly if a grading assistant is available). If an outcome was covered in more than one assignment, the assignment scores were averaged with equal weights. Representative results for three students are shown in Table 4.

\begin{tabular}{|c|c|c|c|c|c|c|c|c|c|c|}
\hline \multirow{2}{*}{$\begin{array}{l}\text { Student } \\
\text { name }\end{array}$} & \multicolumn{10}{|c|}{ Outcome } \\
\hline & 1 & 2 & 3 & 4 & 5 & 6 & 7 & 8 & 9 & 10 \\
\hline Student 1 & 76 & 76 & 85.5 & 75 & 15 & 75 & 75 & 100 & 89 & 100 \\
\hline Student 8 & 79 & 79 & 87 & 85 & 80 & 85 & 85 & 100 & 100 & 100 \\
\hline Student 10 & 65 & 65 & 68.5 & 70 & 61 & 70 & 70 & 100 & 89 & 100 \\
\hline
\end{tabular}

Table 4. Outcome averages from homework and inclass assignments

The same method was followed for exams. The result is seen in Table 5. Note that columns for outcomes 2 and 3 are blank because no exam problems covered those outcomes.

\begin{tabular}{|c|c|c|c|c|c|c|c|c|c|c|}
\hline \multirow{2}{*}{$\begin{array}{l}\text { Student } \\
\text { name }\end{array}$} & \multicolumn{10}{|c|}{ Outcome } \\
\hline & 1 & 2 & 3 & 4 & 5 & 6 & 7 & 8 & 9 & 10 \\
\hline Student 1 & 100 & & & 75 & 42.8 & 100 & 100 & 50 & 100 & 33.3 \\
\hline Student 8 & 100 & & & 100 & 42.9 & 100 & 100 & 100 & 85.7 & 100 \\
\hline Student 10 & 50 & & & 37.5 & 28.6 & 71.4 & 42.9 & 66.7 & 42.9 & 66.7 \\
\hline
\end{tabular}

Table 5. Outcome averages from exam problems

An overall outcome average was determined by multiplying $40 \%$ of the homework score with $60 \%$ of the exam score. The scores were not simply averaged because exams were felt to be 
better indicators of a student's actual knowledge since homework performance could be the result of a group effort. The result is seen in Table 6 .

\begin{tabular}{|l|r|r|r|r|r|r|r|r|r|r|}
\hline \multirow{2}{*}{$\begin{array}{l}\text { Student } \\
\text { name }\end{array}$} & \multicolumn{10}{|c|}{ Outcome } \\
\cline { 2 - 11 }$y$ & $\mathbf{1}$ & $\mathbf{2}$ & $\mathbf{3}$ & $\mathbf{4}$ & $\mathbf{5}$ & $\mathbf{6}$ & $\mathbf{7}$ & $\mathbf{8}$ & $\mathbf{9}$ & $\mathbf{1 0}$ \\
\hline Student 1 & 90.4 & 76 & 85.5 & 75 & 31.7 & 90 & 90 & 70 & 95.6 & 60 \\
\hline Student 8 & 91.6 & 79 & 87 & 94 & 57.7 & 94 & 94 & 100 & 91.4 & 100 \\
\hline Student 10 & 56 & 65 & 68.5 & 50.5 & 41.5 & 70.9 & 53.7 & 80 & 61.3 & 80 \\
\hline
\end{tabular}

\section{Table 6. Overall outcome averages}

Grades could be calculated based on overall outcome averages by simple averaging, weighted averaging (which would require a judgment on the relative importance of each outcome), or by other means. For this offering, however, grades were assigned based on the traditional assignment-based scheme.

Table 7 shows that grades based on the traditional assignment-based scheme were typically half a grade higher than those under the outcome-based scheme. The difference between the two is due to the uneven distribution of points assigned to outcomes in assignments and exams. The assignment-based scheme used $40 \%$ of the average homework/inclass assignment score and $60 \%$ of the average exam score.

\begin{tabular}{|l|c|c|c|c|}
\hline \multirow{2}{*}{ Student name } & \multicolumn{2}{|c|}{ Assignment-based } & \multicolumn{2}{c|}{ Outcome-based } \\
\cline { 2 - 5 } & score & grade & score & grade \\
\hline Student 1 & 81.4 & $\mathrm{~B}$ & 76.4 & $\mathrm{~B}-$ \\
\hline Student 8 & 93.4 & $\mathrm{~A}$ & 88.9 & $\mathrm{~B}+$ \\
\hline Student 10 & 68.9 & $\mathrm{C}$ & 62.7 & $\mathrm{C}-$ \\
\hline
\end{tabular}

Table 7. Student grades corresponding to the assignment- and outcome-based schemes 
Class averages are useful for determining how well program outcomes are being achieved. Table 8 shows the average score for each outcome.

\begin{tabular}{|l|c|}
\hline \multicolumn{1}{|c|}{ Outcome } & Class average \\
\hline $\begin{array}{l}\text { 1. Understand global energy use and nonrenewable } \\
\text { energy source depletion rate models }\end{array}$ & 87.6 \\
\hline 2. Design a simple jet engine & 76.6 \\
\hline $\begin{array}{l}\text { 3. Analyze regeneration and reheat enhancements to gas } \\
\text { power cycles }\end{array}$ & 82.9 \\
\hline $\begin{array}{l}\text { 4. Analyze vapor-compression and absorption } \\
\text { refrigeration cycles }\end{array}$ & 80.7 \\
\hline $\begin{array}{l}\text { 5. Perform availability (exergy) analyses on various } \\
\text { systems }\end{array}$ & 58.7 \\
\hline $\begin{array}{l}\text { 6. Analyze operating characteristics of pumps, turbines, } \\
\text { and compressors }\end{array}$ & 84.2 \\
\hline $\begin{array}{l}\text { 7. Use pump and system head curves to size pumps for } \\
\text { piping systems }\end{array}$ & 83.3 \\
\hline 8. Analyze a variety of alternative-energy systems & 92.3 \\
\hline 9. Apply fundamental fuel cell relationships & 81.3 \\
\hline 10. Design energy storage systems & 77.7 \\
\hline
\end{tabular}

\section{Table 8. Class averages for outcomes}

Using the rubric that an outcome is achieved if the class average is at least $70 \%$, all outcomes in this course have been achieved except outcome 5. This is a clear indication that more effort must be focused on exergy analyses in future offerings.

Students also performed a self-evaluation where they were asked to respond to the question "I feel this course enabled me to ..." for each of the outcomes, rating their response on a scale of 1 to 5, with 1 being "strongly disagree" and 5 being "strongly agree". The results are seen in Table 9. 


\begin{tabular}{|l|c|}
\hline \multicolumn{1}{|c|}{ Outcome } & Class average \\
\hline $\begin{array}{l}\text { 1. Understand global energy use and nonrenewable } \\
\text { energy source depletion rate models }\end{array}$ & 4.4 \\
\hline 2. Design a simple jet engine & 4 \\
\hline $\begin{array}{l}\text { 3. Analyze regeneration and reheat enhancements to gas } \\
\text { power cycles }\end{array}$ & 4.4 \\
\hline $\begin{array}{l}\text { 4. Analyze vapor-compression and absorption } \\
\text { refrigeration cycles }\end{array}$ & 4.2 \\
\hline $\begin{array}{l}\text { 5. Perform availability (exergy) analyses on various } \\
\text { systems }\end{array}$ & 4.4 \\
\hline $\begin{array}{l}\text { 6. Analyze operating characteristics of pumps, turbines, } \\
\text { and compressors }\end{array}$ & 4.3 \\
\hline $\begin{array}{l}\text { 7. Use pump and system head curves to size pumps for } \\
\text { piping systems }\end{array}$ & 3.9 \\
\hline 8. Analyze a variety of alternative-energy systems & 4 \\
\hline 9. Apply fundamental fuel cell relationships & 4.3 \\
\hline 10. Design energy storage systems & 4.1 \\
\hline
\end{tabular}

Table 9. Class response averages (on a scale 1 to 5) on the student self-evaluation

Table 10 compares student and instructor rankings of how well outcomes were achieved. Interestingly, with the exception of outcome 1, there is not much correlation between the student and instructor assessments. For instance, the students ranked outcome 5, identified by the instructor as not being achieved, as one of their highest achievements. This may be explained by the fact that outcome 5 was assessed by a very long homework assignment and although student performance was relatively poor, students may have felt the grading was too harsh. Outcome 7 was ranked last by the students while the instructor assessed this outcome as one of the highest. In this case the discrepancy may be explained by the fact that the homework assignment covered more than one outcome and, as explained above, the assignment score was applied to all relevant outcomes, thus masking poor performance on a single homework problem. 


\begin{tabular}{|c|c|}
\hline Student self assessment ranking & Instructor assessment ranking \\
\hline $\begin{array}{l}\text { 1. Understand global energy use and nonrenewable } \\
\text { energy source depletion rate models }\end{array}$ & 8. Analyze a variety of alternative-energy systems \\
\hline $\begin{array}{l}\text { 3. Analyze regeneration and reheat enhancements to } \\
\text { gas power cycles }\end{array}$ & $\begin{array}{l}\text { 1. Understand global energy use and nonrenewable } \\
\text { energy source depletion rate models }\end{array}$ \\
\hline $\begin{array}{l}\text { 5. Perform availability (exergy) analyses on various } \\
\text { systems }\end{array}$ & $\begin{array}{l}\text { 6. Analyze operating characteristics of pumps, } \\
\text { turbines, and compressors }\end{array}$ \\
\hline $\begin{array}{l}\text { 6. Analyze operating characteristics of pumps, } \\
\text { turbines, and compressors }\end{array}$ & $\begin{array}{l}\text { 7. Use pump and system head curves to size pumps for } \\
\text { piping systems }\end{array}$ \\
\hline 9. Apply fundamental fuel cell relationships & $\begin{array}{l}\text { 3. Analyze regeneration and reheat enhancements to } \\
\text { gas power cycles }\end{array}$ \\
\hline $\begin{array}{l}\text { 4. Analyze vapor-compression and absorption } \\
\text { refrigeration cycles }\end{array}$ & 9. Apply fundamental fuel cell relationships \\
\hline 10. Design energy storage systems & $\begin{array}{l}\text { 4. Analyze vapor-compression and absorption } \\
\text { refrigeration cycles }\end{array}$ \\
\hline 2. Design a simple jet engine & 10. Design energy storage systems \\
\hline 8. Analyze a variety of alternative-energy systems & 2. Design a simple jet engine \\
\hline $\begin{array}{l}\text { 7. Use pump and system head curves to size pumps for } \\
\text { piping systems }\end{array}$ & $\begin{array}{l}\text { 5. Perform availability (exergy) analyses on various } \\
\text { systems }\end{array}$ \\
\hline
\end{tabular}

Table 10. Outcomes ranked from highest to lowest degree of achievement by students and instructor.

Using the above results, the instructor has a clear metric for addressing course, and by extension program, outcomes in the course worksheet. The student self assessment results give indirect evidence of student performance and are thus of limited value except to indicate student confidence for those cases where the direct assessment results from assignments corroborate the self-perception data.

\section{Planned Improvements to the Assessment Process}

The outcome-based assessment scheme described above has some drawbacks. One is that outcome results are "smeared" when scores for a single assignment covering multiple outcomes are assigned to all outcomes, in lieu of distinguishing among outcomes within assignments. Secondly, student grades are not assigned based on achievement of outcomes. In the future, these drawbacks will be eliminated by generating a separate spreadsheet for each student similar to that shown in Table 11. A weighted average for each outcome will be calculated based on the instructor's opinion of how rigorously an outcome was assessed in any given assignment. Having determined outcome scores for each student, a table similar to Table 4 will be generated, with final class grades determined based on weighted averages of all the outcomes. The syllabus will reflect this new grading scheme. 


\begin{tabular}{|l|r|r|r|r|r|r|r|r|r|r|}
\hline \multicolumn{10}{|c|}{ Student name } \\
\hline \multirow{2}{*}{ Assignment } & \multicolumn{9}{|c|}{ Outcome } \\
\cline { 2 - 12 } & $\mathbf{1}$ & $\mathbf{2}$ & $\mathbf{3}$ & $\mathbf{4}$ & $\mathbf{5}$ & $\mathbf{6}$ & $\mathbf{7}$ & $\mathbf{8}$ & $\mathbf{9}$ & $\mathbf{1 0}$ \\
\hline HW 1 & 100 & & & & & & & & & \\
\hline HW 3 & & 80 & & & & & & & & \\
\hline HW 4 & & & 90 & 86 & & & & & & \\
\hline HW 5 & & & & & & & & 78 & 88 & 99 \\
\hline Exam 1 & 75 & 68 & & & & & & & & \\
\hline Exam 2 & & & & & 85 & 93 & 69 & & & \\
\hline Inclass 1 & 30 & & & & & & & & & \\
\hline Inclass 2 & & & & 95 & & & & & & \\
\hline Project & 60 & 80 & & 80 & & 25 & 100 & 85 & 90 & 85 \\
\hline $\begin{array}{l}\text { Weighted } \\
\text { average }\end{array}$ & 73.5 & 75.2 & 90 & 86.5 & 79 & 68.7 & 76.5 & 82.9 & 89.4 & 89.2 \\
\hline
\end{tabular}

Table 11. Spreadsheet example for future offerings (scores are fictitious and assignment types are merely representative). The calculation of the weighted average differs with outcome.

In an effort to improve agreement between instructor and student self assessment, students could be alerted as to which outcomes are being assessed on any given assignment. This designation may not be appropriate for all assignments, as students should develop the ability to recognize classes of problems by themselves (a goal consistent with ABET criteria 3(e) that students have the ability to identify engineering problems). The instructor could also provide periodic updates on the course website indicating how well students are doing with respect to any particular outcome.

\section{Conclusions}

The method described in this paper provides a quantitative way for instructors to assess course outcomes. The resulting data provides a robust underpinning for relevant program outcomes, and helps the instructor identify problem areas. Several enhancements to the method will provide even more useful information for both instructor feedback and student self assessment.

Bibliography

1. ABET. Guidelines to Institutions, Team Chairs and Program Evaluators on Interpreting and Meeting the Standards Set Forth in Criterion 3 of the Engineering Accreditation Criteria. Document from ABET website http://www.abet.org/info_prgs.html

2. Felder, Richard M. and Brent, Rebecca. Designing and Teaching Courses to Satisfy the ABET Engineering Criteria. Journal of Engineering Education, pp. 7-25 (January 2003).

3. Soundarajan, Neelam. Preparing for Accreditation Under EC 2000: An Experience Report. Journal of Engineering Education, pp. 117-123 (January 2002).

4. Pape, David A. and Eddy, Pamela L. Setup of a Course Level Assessment for ABET 2000. Proceedings of the 2004 American Society for Engineering Education Annual Conference \& Exposition (June 2000). 
MARK SCHUMACK

Mark Schumack is Associate Professor of Mechanical Engineering at the University of Detroit Mercy. He teaches courses in heat transfer, thermodynamics, fluid mechanics, and energy systems. His research interests include thermal/fluid modeling using computational techniques, with applications in the automotive and manufacturing fields. Dr. Schumack earned his BS, MS, and Ph.D. degrees in Mechanical Engineering from the University of Michigan. 


\section{Appendix}

\section{Course Worksheet}

Course number and name:

Term taught:

Number of students completing course:

Instructor name:

1) List course outcomes, describe how each outcome was assessed, and state the degree to which each was satisfied. Attach supporting surveys.

\begin{tabular}{|l|l|l|}
\hline Outcome & Assessment method & Degree of achievement \\
\hline 1. (course outcome) & $\begin{array}{l}\text { (specific exam problems, } \\
\text { homework problems, projects, } \\
\text { student surveys) }\end{array}$ & $\begin{array}{l}\text { (brief statement on how well } \\
\text { outcome was achieved for the } \\
\text { class overall; highlight problem } \\
\text { areas) }\end{array}$ \\
\hline 2. etc. & & \\
\hline
\end{tabular}

2) Discuss plans for subsequent offerings of this course based on assessment results.

3) Describe progress on action items from previous worksheet(s).

4) Describe any modifications to objectives and outcomes - deletions, additions, and revisions.

5) Comment on student evaluations (attach, if appropriate, copies of student evaluation forms).

6) Are assessment methods appropriate for gauging student achievement of outcomes and objectives? Describe recommended changes.

7) Comment on linkages between course and program outcomes. Should specific linkages be added or deleted?

8) State whether the course has significant design content. If so, state what percentage of student grade is assigned to design-related material. Describe the project(s), including how the project addresses economic, environmental, sustainability, manufacturability, ethical, health and safety, social, and political considerations. Also, state whether and to what extent teamwork and communication were addressed. 